\title{
In the balance: External troop support and rebel fragmentation in the Second Congo War
}

\author{
Henning Tamm \\ School of International Relations \\ University of St Andrews \\ ht37@st-andrews.ac.uk \\ Forthcoming in Journal of Strategic Studies \\ AUTHOR ACCEPTED MANUSCRIPT - NOT THE FINAL VERSION. \\ PLEASE DO NOT CITE OR CIRCULATE WITHOUT THE AUTHOR'S PERMISSION.
}

24 November 2019

\section{Abstract}

The two main rebel groups in the Second Congo War (1998-2003) evolved in remarkably different ways. While the MLC maintained organisational cohesion throughout the war, the RCD split into two rival groups within less than a year. The larger of these rivals then remained cohesive, whereas the smaller group experienced further fragmentation. This article draws on interviews with key protagonists to show that these cross-group differences resulted from different patterns of state sponsorship. Fragmentation occurred when the intra-group distribution of power between a rebel leader and an internal rival hung in the balance because external troops supported both sides.

\section{Keywords}

External support; rebel groups; fragmentation; cohesion; Democratic Republic of Congo 


\section{Introduction}

The Second Congo War, often called Africa's deadliest conflict, ${ }^{1}$ featured two major rebel groups. The first group, the Rassemblement congolais pour la démocratie ( $\mathrm{RCD}$, Congolese Rally for Democracy), was created in August 1998 under Rwanda's supervision and initially also received Ugandan support. The second group, the Mouvement de libération $d u$ Congo (MLC, Movement for the Liberation of Congo), emerged in November 1998 under Uganda's sole supervision. By the time the inauguration of a transitional power-sharing government formally ended the conflict in July 2003, the RCD had split into six groups, whereas the MLC remained a cohesive organisation (Figure 1). What explains the striking difference between the RCD's fragmentation and the MLC's cohesion? Even more intriguingly, what explains why each successive RCD split led to one cohesive group and another that further splintered?

\begin{tabular}{|c|c|c|c|c|c|c|c|}
\hline 1998 & \multirow[t]{6}{*}{$\begin{array}{c}\text { MLC } \\
\text { (Uganda) }\end{array}$} & \multicolumn{6}{|c|}{$\begin{array}{c}\mathrm{RCD} \\
\text { (Rwanda, Uganda) }\end{array}$} \\
\hline 1999 & & \multirow[t]{5}{*}{$\begin{array}{c}\mathrm{RCD} \\
\text { (Rwanda) }\end{array}$} & \multicolumn{5}{|c|}{$\begin{array}{c}\mathrm{RCD}-\mathrm{K} / \mathrm{ML} \\
\text { (Uganda) }\end{array}$} \\
\hline 2000 & & & \multirow[t]{4}{*}{$\begin{array}{l}\text { RCD-N } \\
\text { (Uganda) }\end{array}$} & \multicolumn{4}{|c|}{$\begin{array}{l}\text { RCD-K/ML } \\
\text { (Uganda) }\end{array}$} \\
\hline 2001 & & & & & & & \\
\hline 2002 & & & & \multirow[t]{2}{*}{$\begin{array}{c}\mathrm{RCD}-\mathrm{K} / \mathrm{ML} \\
(D R C)\end{array}$} & \multicolumn{3}{|c|}{$\begin{array}{c}\mathrm{UPC} \\
\text { (Uganda, Rwanda) }\end{array}$} \\
\hline 2003 & & & & & $\begin{array}{c}\text { FAPC } \\
(\text { Uganda) }\end{array}$ & $\begin{array}{c}\text { PUSIC } \\
(U g a n d a, D R C)\end{array}$ & $\begin{array}{c}\text { UPC } \\
\text { (Rwanda) }\end{array}$ \\
\hline
\end{tabular}

(Note: Each group's state sponsors are listed in brackets.)

Figure 1. Organisational evolution of the MLC and the RCD, August 1998 - June 2003.

Building on recent theoretical work, ${ }^{2}$ this article argues that different allocations of external resources by state sponsors best account for the variation in rebel group cohesion during the Second Congo War. Rwanda and Uganda, which sent thousands of troops to fight on the

\footnotetext{
${ }^{1}$ Walter C. Soderlund et al., Africa's Deadliest Conflict: Media Coverage of the Humanitarian Disaster in the Congo and the United Nations Response, 1997-2008 (Waterloo: Wilfrid Laurier University Press 2012); Philip Roessler and Harry Verhoeven, Why Comrades Go To War: Liberation Politics and the Outbreak of Africa's Deadliest Conflict (New York: Oxford University Press 2016).

${ }^{2}$ Henning Tamm, 'Rebel Leaders, Internal Rivals, and External Resources: How State Sponsors Affect Insurgent Cohesion', International Studies Quarterly 60/4 (2016) 599-610.
} 
rebel side, ${ }^{3}$ helped either to hold groups together or to tear them apart. This does not mean, however, that Congolese rebels were helpless 'puppets' whose foreign masters pulled their strings at will, as Georges Nzongola-Ntalaja suggests. ${ }^{4}$ In fact, it was the defiant behaviour of rebel leaders - who exploited inter-state rivalries - that led their sponsors to instigate most of the splits.

I also do not mean to suggest that state sponsors alone caused all ten organisational outcomes studied in this article. The Second Congo War was incredibly complex. In the online appendix, I try to do justice to this complexity by providing an overview of which additional causal factors help explain particular outcomes. The main purpose of the article itself, however, is to show that, despite the war's complexity, a theoretical focus on external resource allocation reveals some reasonably simple recurring patterns. This schematic approach aims to make the war more accessible to a general strategic studies audience. By drawing on interviews with key protagonists, the article also provides the most fine-grained illustrations to date of the allocation theory's causal mechanisms.

More generally, the article advances the theoretical study of rebel fragmentation by elucidating how state sponsors that provide significant troop support can directly determine the outcome of intra-group rivalries and empower even internal rivals who lack local power bases. It thus contributes to a growing literature on the effects of different types of external support. ${ }^{5}$ According to a widely used dataset, sixteen percent of all rebel groups active between 1945 and 2011 received external troop support. ${ }^{6}$ The high level of troop support witnessed in the Second Congo War is by no means exceptional. Several other states sent thousands of soldiers into neighbouring countries to fight alongside rebel groups or movements they helped create, including North Vietnam (into Cambodia in 1970), Somalia (into Ethiopia in 1977), Tanzania

\footnotetext{
${ }^{3}$ The highest self-reported troop figures are 23,760 for Rwanda and 9,600 for Uganda. See United Nations Security Council (UNSC), 'Twelfth Report of the Secretary-General on the United Nations Organization Mission in the Democratic Republic of the Congo', S/2002/1180, New York, 18 October 2002, para. 10; Republic of Uganda, 'Judicial Commission of Inquiry into Allegations into Illegal Exploitation of Natural Resources and Other Forms of Wealth in the Democratic Republic of Congo 2001 (May 2001 - June 2002): Transcript', June 2002, 82, 94 (on file with the author). These figures match the estimates in International Crisis Group (ICG), 'Scramble for the Congo: Anatomy of an Ugly War', Nairobi/Brussels, 20 December 2000, 4.

${ }^{4}$ Georges Nzongola-Ntalaja, The Congo from Leopold to Kabila: A People's History (London: Zed Books 2002), 229.

${ }^{5}$ On external bases, see Idean Salehyan, 'Transnational Rebels: Neighboring States as Sanctuary for Rebel Groups', World Politics 59/2 (2007) 217-42. On money and weapons, see Katherine Sawyer, Kathleen Gallagher Cunningham, and William Reed, 'The Role of External Support in Civil War Termination', Journal of Conflict Resolution 61/6 (2017) 1174-202.

${ }^{6}$ David E. Cunningham, Kristian Skrede Gleditsch, and Idean Salehyan, 'Non-State Actors in Civil Wars: A New Dataset', Conflict Management and Peace Science 30/5 (2013) 516-31.
} 
(into Uganda in 1979), Libya (into Chad in the 1980s), and Armenia (into Azerbaijan in 1992). ${ }^{7}$

Russia's troop support to separatist rebels in eastern Ukraine provides the most prominent recent example: US military estimates from March 2015 suggest the involvement of around 12,000 Russian soldiers. ${ }^{8}$ I discuss similarities between Rwandan, Ugandan, and not only Russian but also North Vietnamese and Somali sponsorship patterns in the conclusion.

The article draws on dozens of interviews conducted in the Democratic Republic of Congo (DRC), Rwanda, and Uganda between 2011 and 2014. In Congo, I interviewed former senior rebel officials, among them four of the five RCD and RCD-K/ML presidents. In Rwanda and Uganda, I spoke to senior civilian and military officials; only three of them are referenced here, but several others provided important background information. ${ }^{9}$ I triangulate these interviews with a wide range of sources, including the substantial secondary and grey literature on the war.

The following section defines rebel fragmentation and provides a brief overview of the theoretical literature. The third section delineates the patterns of external resource allocation that are relevant for the Second Congo War. The fourth section presents historical background to the war and explains the research design of this study, which leverages three paired comparisons, each comprising one group that remained cohesive and another that split in roughly the same time period. The next three sections contain the comparative analyses. The concluding section summarises the main implications of the findings for the allocation theory and outlines promising avenues for future research.

\section{Definitions and theories of rebel fragmentation}

Among civil war scholars, there has been a surge of interest in rebel fragmentation. ${ }^{10}$ Some scholars define fragmentation by focusing on rebel movements that contain multiple groups.

\footnotetext{
${ }^{7}$ Stephen J. Morris, Why Vietnam Invaded Cambodia: Political Culture and the Causes of War (Stanford, CA: Stanford University Press 1999), 48-50; Gebru Tareke, 'The Ethiopia-Somalia War of 1977 Revisited', International Journal of African Historical Studies 33/3 (2000) 635-67, 642-44; George Roberts, 'The UgandaTanzania War, the Fall of Idi Amin, and the Failure of African Diplomacy, 1978-1979', Journal of Eastern African Studies 8/4 (2014) 692-709, 699; Sam C. Nolutshungu, Limits of Anarchy: Intervention and State Formation in Chad (Charlottesville, VA: University Press of Virginia 1996), chaps. 4-7; Thomas De Waal, Black Garden: Armenia and Azerbaijan through Peace and War (New York: New York University Press 2003), 210.

${ }^{8}$ Maksymilian Czuperski et al., 'Hiding in Plain Sight: Putin's War in Ukraine', Atlantic Council, Washington DC, May 2015, 15. For background, see Andrew S. Bowen, 'Coercive Diplomacy and the Donbas: Explaining Russian Strategy in Eastern Ukraine', Journal of Strategic Studies 42/3-4 (2019) 312-43.

9 On the challenges of this methodology, see Jeffrey M. Berry, 'Validity and Reliability Issues in Elite Interviewing', PS: Political Science \& Politics 35/4 (2002) 679-82.

${ }_{10}$ Wendy Pearlman and Kathleen Gallagher Cunningham, 'Nonstate Actors, Fragmentation, and Conflict Processes', Journal of Conflict Resolution 56/1 (2012) 3-15; Caitriona Dowd, 'Actor Proliferation and the Fragmentation of Violent Groups in Conflict', Research and Politics 2/4 (2015) 1-7.
} 
Their studies investigate the number of distinct organisations, the relative distribution of power among them, and the degree of institutionalisation across them, linking these three dimensions to the probability of infighting and the likelihood of achieving the movement's overall goals. ${ }^{11}$ From this perspective, the Ugandan-led creation of the Front de libération du Congo (FLC, Front for the Liberation of Congo) in January 2001 - an 'umbrella organisation'12 that institutionalised cooperation between the MLC, the RCD-Kisangani/Mouvement de libération (RCD$\mathrm{K} / \mathrm{ML}$, Liberation Movement), and the RCD-National (RCD-N) - would be of major analytical importance.

Other scholars, by contrast, focus on the fragmentation of rebel groups or, synonymously, organisations. ${ }^{13}$ They define fragmentation as 'an event in which part of a group refuses to recognize the existing leader's command authority and breaks away to form a separate organization with its own leadership and chain of command' ${ }^{14}$ This second perspective is adopted here, which explains why the FLC does not feature in Figure 1.

Theory-driven research has provided several different answers to the central question of why some rebel groups experience fragmentation whereas others maintain cohesion over long periods of time. These answers revolve around geography and technology, 15 'lootable' natural resources,${ }^{16}$ peace negotiations, ${ }^{17}$ battlefield performance, ${ }^{18}$ foreign fighters,${ }^{19}$ pre-war social

11 Kristin M. Bakke, Kathleen Gallagher Cunningham, and Lee J. M. Seymour, 'A Plague of Initials: Fragmentation, Cohesion, and Infighting in Civil Wars', Perspectives on Politics 10/2 (2012) 265-83; Peter Krause, 'The Structure of Success: How the Internal Distribution of Power Drives Armed Group Behavior and National Movement Effectiveness', International Security 38/3 (2013/14) 72-116.

12 Gauthier de Villers, Jean Omasombo, and Erik Kennes, République démocratique du Congo: Guerre et politique - Les trente derniers mois de L. D. Kabila (août 1998-janvier 2001) (Tervuren: Institut africain 2001), 110.

13 Paul D. Kenny, 'Structural Integrity and Cohesion in Insurgent Organizations: Evidence from Protracted Conflicts in Ireland and Burma', International Studies Review 12/4 (2010) 533-55; Paul Staniland, Networks of Rebellion: Explaining Insurgent Cohesion and Collapse (Ithaca, NY: Cornell University Press 2014); Michael Woldemariam, Insurgent Fragmentation in the Horn of Africa: Rebellion and Its Discontents (Cambridge: Cambridge University Press 2018).

14 Tamm, 'Rebel Leaders', 600.

15 Scott Gates, 'Recruitment and Allegiance: The Microfoundations of Rebellion', Journal of Conflict Resolution 46/1 (2002) 111-30; Patrick Johnston, 'The Geography of Insurgent Organization and its Consequences for Civil Wars: Evidence from Liberia and Sierra Leone', Security Studies 17/1 (2008) 107-37.

${ }^{16}$ Jeremy M. Weinstein, Inside Rebellion: The Politics of Insurgent Violence (Cambridge: Cambridge University Press 2007); Nicholai Hart Lidow, Violent Order: Understanding Rebel Governance through Liberia 's Civil War (New York: Cambridge University Press 2016).

${ }^{17}$ Wendy Pearlman, 'Spoiling Inside and Out: Internal Political Contestation and the Middle East Peace Process', International Security 33/3 (2008/9) 79-109; Marie Olson Lounsbery and Alethia H. Cook, 'Rebellion, Mediation, and Group Change: An Empirical Investigation of Competing Hypotheses', Journal of Peace Research 48/1 (2011) 73-84.

18 Fotini Christia, Alliance Formation in Civil Wars (Cambridge: Cambridge University Press 2012); Woldemariam, Insurgent Fragmentation.

19 Kristin M. Bakke, 'Help Wanted? The Mixed Record of Foreign Fighters in Domestic Insurgencies', International Security 38/4 (2014) 150-87. 
bases, ${ }^{20}$ indiscriminate state violence, ${ }^{21}$ state sponsors, ${ }^{22}$ ideology, ${ }^{23}$ and personal loyalties. ${ }^{24}$ In the online appendix, I consider all these factors as explanations for rebel cohesion and fragmentation in the Second Congo War. Social bases emerge as the second most powerful explanation: the theory correctly predicts eight of the ten outcomes, with strong support for its hypothesised mechanism in five cases. Theories focused on geography, natural resources, and battlefield performance correctly predict either five or six outcomes, but their hypothesised mechanisms are strongly supported in at best only three cases. By contrast, the external resource allocation theory correctly predicts all ten outcomes, with strong evidence for its mechanisms in nine cases. ${ }^{25}$ Given that only the allocation theory can explain more than half of the outcomes, the remainder of this article focuses solely on that theory.

\section{Patterns of external resource allocation and their effect on rebel groups}

State sponsors can directly determine the likelihood of rebel fragmentation by allocating their resources in ways that either stabilise or disrupt the existing distribution of power within a rebel group. ${ }^{26}$ Rebellions attract ambitious individuals. Virtually all groups thus feature internal rivals who would be willing to challenge the existing rebel leader if they were given enough resources to make such a challenge viable. This is where state sponsors come in. If their support consists of money and/or weapons, they can ensure that these external resources are sent to the individual they favour - either the leader or the rival. If sponsors intervene directly (the focus of this article) or if a group makes extensive use of rear bases in the territory of sponsors, they can tip the balance even more decisively by ordering their troops to take sides in intra-group rivalries. ${ }^{27}$ The larger the number of troops that sponsors send to fight alongside the rebel group, the more likely it is that external resource allocation alone will determine organisational outcomes.

\footnotetext{
${ }^{20}$ Staniland, Networks of Rebellion.

${ }^{21}$ Livia Isabella Schubiger, 'One for All? State Violence and Insurgent Cohesion', paper presented at the Annual Convention of the International Studies Association, New Orleans, LA, February 2015.

${ }^{22}$ Marie Olson Lounsbery, 'Foreign Military Intervention, Power Dynamics, and Rebel Group Cohesion', Journal of Global Security Studies 1/2 (2016) 127-41; Tamm, 'Rebel Leaders'.

${ }^{23}$ Aisha Ahmad, 'Going Global: Islamist Competition in Contemporary Civil Wars', Security Studies 25/2 (2016) 353-84; Mohammed M. Hafez, 'Fratricidal Rebels: Ideological Extremity and Warring Factionalism in Civil Wars', Terrorism and Political Violence, published online on 29 November 2017.

${ }^{24}$ Eric S. Mosinger, 'Balance of Loyalties: Explaining Rebel Factional Struggles in the Nicaraguan Revolution', Security Studies 28/5 (2019) 935-75.

${ }^{25}$ The theory was originally developed on the basis of some of these cases, which explains its perfect 'predictive' record. This article provides an elaboration and detailed illustration of the theory; it does not 'test' the theory.

${ }^{26}$ This section builds on Tamm, 'Rebel Leaders', 600-03.

${ }^{27}$ For example, in 2009, Rwanda arrested Congolese rebel leader Laurent Nkunda on its own territory, thereby helping his internal rival, Bosco Ntaganda, take over the group. Jason Stearns, From CNDP to M23: The Evolution of an Armed Movement in Eastern Congo (London: Rift Valley Institute 2012), 34-35.
} 
Table 1 visualises the three main allocation patterns, illustrates that different numbers of sponsors at different times lead to slight variations in a given pattern, and lists the cases from the Second Congo War that match each pattern. The first pattern, united and consistent sponsorship, should lead to organisational cohesion, meaning simply the absence of fragmentation. Sponsorship is 'united' in that the sponsor allocates resources only to the existing leader, not to the internal rival, and it is 'consistent' in that the sponsor does so both at the start $\left(\mathrm{T}_{0}\right)$ and at the end $\left(T_{1}\right)$ of the time period under consideration. Assuming rivals are not unduly riskacceptant, united support for the leader should deter them from launching a challenge. Instead, they are more likely to defect from or leave the group. ${ }^{28}$

Table 1. Patterns of external resource allocation and their organisational consequences.

\begin{tabular}{|c|c|c|c|c|}
\hline & Allocation at $\mathrm{T}_{0}$ & Allocation at $\mathrm{T}_{1}$ & & No. of cases (at $\left.T_{1}\right)$ \\
\hline \multicolumn{5}{|c|}{ United and consistent sponsorship: cohesion } \\
\hline (1) & $\begin{aligned} \text { Sponsor } \longrightarrow & \text { Leader } \\
& \text { Rival }\end{aligned}$ & Sponsor & $\begin{array}{l}\text { Leader } \\
\text { Rival }\end{array}$ & $\begin{array}{l}2 \text { (MLC, Jun. 2003; } \\
\text { RCD-K/ML, Jun. 2003) }\end{array}$ \\
\hline \multicolumn{5}{|c|}{ United but shifting sponsorship: cohesion with takeover } \\
\hline (2) & 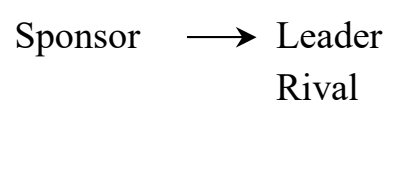 & Sponsor & $\begin{array}{l}\text { Leader } \\
\text { Rival }\end{array}$ & $\begin{array}{l}3 \text { (RCD, Oct. 2000; } \\
\text { RCD-K/ML, Nov. 2000; } \\
\text { RCD, Jun. 2003) }\end{array}$ \\
\hline \multicolumn{5}{|c|}{ From united to divided sponsorship: fragmentation } \\
\hline$(3 a)$ & 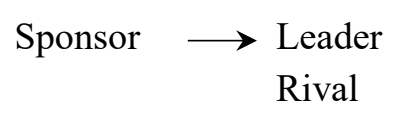 & Sponsor & $\begin{array}{l}\text { Leader } \\
\text { Rival }\end{array}$ & 1 (RCD-K/ML, Jun. 2000) \\
\hline$(3 b)$ & $\begin{array}{c}\text { Sponsor } 1 \longrightarrow \\
\text { Rival }\end{array}$ & $\left.\begin{array}{l}\text { Sponsor } 1 \\
\text { Sponsor } 2\end{array}\right\rangle$ & $\begin{array}{l}\text { Leader } \\
\text { Rival }\end{array}$ & $\begin{array}{r}3 \text { (RCD-K/ML, Aug. 2002; } \\
\text { UPC, Mar. 2003: PUSIC; } \\
\text { UPC, Mar. 2003: FAPC) }\end{array}$ \\
\hline$(3 c)$ & $\begin{array}{l}\text { Sponsor } 1 \longrightarrow \begin{array}{l}\text { Leader } \\
\text { Sponsor } 2\end{array} \\
\text { Rival }\end{array}$ & $\begin{array}{l}\text { Sponsor } 1 \\
\text { Sponsor } 2\end{array}$ & $\begin{array}{l}\text { Leader } \\
\text { Rival }\end{array}$ & 1 (RCD, May 1999) \\
\hline
\end{tabular}

The second pattern, united but shifting sponsorship, should also lead to cohesion but involve a takeover by the rival. In this case, sponsorship is 'united' because at each point in time

\footnotetext{
${ }^{28}$ On defection and exit, see Stathis N. Kalyvas, 'Ethnic Defection in Civil War', Comparative Political Studies 41/8 (2008) 1043-68; Ben Oppenheim et al., 'True Believers, Deserters, and Traitors: Who Leaves Insurgent Groups and Why', Journal of Conflict Resolution 59/5 (2015) 794-823. On the desertion of low-level combatants during and after the Congo Wars, see Joanne Richards, 'Troop Retention in Civil Wars: Desertion, Denunciation, and Military Organization in the Democratic Republic of Congo', Journal of Global Security Studies 3/1 (2018) $38-55$.
} 
all the sponsor's support is united behind one individual, but it is 'shifting' in the sense of being redirected from the leader to the rival. I use the term 'takeover', which Fotini Christia introduced to the rebel fragmentation literature, ${ }^{29}$ instead of 'internal coup' since the former is more open to meaning either an orderly, non-violent or a less orderly, violent leadership change. The discussions below of the two RCD takeovers instigated by Rwanda in October 2000 and June 2003 show that takeovers can be orderly, that is, follow formal organisational procedures. The first takeover also illustrates that state sponsors which provide significant troop support can bring to power even rivals who have no power base within the group.

The third pattern, from united to divided sponsorship, should lead to fragmentation. Sponsorship is 'divided' at $\mathrm{T}_{1}$ in that both the leader and the rival receive external support. Assuming similar levels of support for each side, this pattern creates a balance of power within the group. It enables the rival to challenge the leader, but it also makes a takeover unlikely. Instead, and especially in cases where external troops protect the rival, the most likely outcome is an organisational split. Table 1 displays the three variants of this basic pattern that occurred during the Second Congo War. In the first, seemingly paradoxical variant, a state decides to back an internal rival while also continuing to support the existing rebel leader. This occurs either when a state, acting in a unitary fashion, employs a divide-and-rule strategy or when different elements within the sponsoring state's security apparatus are themselves divided and back different individuals within the rebel group. The RCD-N's split from the RCD-K/ML in June 2000 suggests that it may not even be obvious which of these two scenarios pertain, as the Ugandan president's control over his armed forces was called into question.

In the second variant, a rebel group is initially supported only by one state, which backs the leader. Over time, however, the leader and the sponsor fall out, the leader finds a new state sponsor, and the original sponsor seeks to punish the leader by redirecting its support to the leader's internal rival. The new sponsor may be either the government against which the rebel leader initially fought (indicating that the leader decided to switch sides in the conflict) or another foreign state, typically a rival of the original sponsor. The RCD-K/ML's fragmentation in April 2002 represents the former scenario; the three-way split of the Union des patriotes congolais (UPC, Union of Congolese Patriots) in March 2003 represents the latter.

In the third variant, a rebel leader has the backing of two state sponsors at the start, but the leader and one of the states then fall out with the other state, leading that state to re-allocate its resources to the rival. As in the previous variant, an inter-state rivalry fuels an intra-group

\footnotetext{
${ }^{29}$ Christia, Alliance Formation, 11.
} 
rivalry, resulting in an organisational split. In the Second Congo War, it was the emerging rivalry between Rwanda and Uganda - erstwhile allies - that in May 1999 initiated the rebel side's progressive fragmentation. Before analysing these processes in more detail, some background on the war is in order.

\section{Historical background and research design}

The origins of the Second Congo War, which began in August 1998, date back to the Rwandan genocide in $1994 .{ }^{30}$ At the end of that genocide, the Rwandan Patriotic Front (RPF) seized power in Rwanda's capital Kigali. In the meantime, the génocidaires - the deposed government, its armed forces, and the Interahamwe militia - by and large fled to eastern Congo (then called Zaire) amidst more than a million refugees. Supported by Zaire's President Mobutu Sese Seko, the génocidaires soon launched incursions into Rwanda. In October 1996, the RPF government responded to this cross-border threat by creating a Zairian rebel movement while simultaneously invading eastern Zaire. Uganda and Angola also supported the rebels in this First Congo War. It ended in May 1997, when Laurent Kabila was installed as the new president in Kinshasa. He changed the country's name to the DRC.

Following a breakdown of relations with Kabila, the Rwandan government instigated a new rebellion in August 1998 - led by the RCD - and again invaded, launching the Second Congo War. Uganda quickly joined the RCD's fight against Kabila but also helped create another rebel group, the MLC. This time, however, Angola, as well as Chad, Namibia, Sudan, and Zimbabwe intervened on the president's side, leading to a military deadlock that was resolved by diplomatic means at the end of 2002. As a result, the main conflict parties formed a transitional government, which began its work in July 2003.

During this second war, as already discussed above (and shown in Figure 1), the rebel side suffered several cases of fragmentation. In May 1999, the RCD split into two separate organisations: the larger Rwandan-backed RCD-Goma (or simply RCD) and the smaller Ugandanbacked RCD-K/ML. In 2000, the RCD-K/ML witnessed both the creation of the RCD-N splinter and an internal coup. From April to August 2002, the RCD-K/ML then lost a significant part of its armed forces to the UPC in a split in Ituri District (north-eastern Congo), which

\footnotetext{
${ }^{30}$ For detailed accounts of the background summarised in the following paragraphs, see Gérard Prunier, Africa's World War: Congo, the Rwandan Genocide, and the Making of a Continental Catastrophe (New York: Oxford University Press 2009); Filip Reyntjens, The Great African War: Congo and Regional Geopolitics, 1996-2006 (Cambridge: Cambridge University Press 2009); Jason K. Stearns, Dancing in the Glory of Monsters: The Collapse of the Congo and the Great War of Africa (New York: Public Affairs 2011); and Roessler and Verhoeven, Why Comrades Go To War.
} 
increasingly turned into both a direct and indirect battleground for the Congolese, Rwandan, and Ugandan governments. In March 2003, the UPC itself split into three, with the Parti pour l'unité et la sauvegarde de l'intégrité du Congo (PUSIC, Party for Unity and Safeguarding of the Integrity of Congo) and the Forces armées du peuple congolais (FAPC, Armed Forces of the Congolese People) as breakaway groups. In stark contrast, the MLC did not suffer any splits between 1998 and 2003, and neither did the RCD after May 1999, the RCD-N after June 2000, nor the RCD-K/ML after August 2002.

In the following sections, I leverage this variation to set up three 'paired comparisons' 31 that, within overlapping time spans, each include an instance of cohesion and at least one of fragmentation: (1) MLC (1998-2003) and RCD (1998-9); (2) RCD (1999-2003) and RCDK/ML (1999-2002); (3) RCD-K/ML (2002-3) and UPC (2002-3). The RCD-N's cohesion is not addressed simply because of the group's marginal overall importance; its splitting off from the RCD-K/ML, however, is analysed as part of the second comparison. Altogether, the three paired comparisons include ten distinct outcomes: five splits, three cases of cohesion with an internal takeover, and two cases of cohesion without a takeover. Table 2 provides an overview of these outcomes, complementing the information provided in Table 1 above.

Table 2. Paired comparisons and outcomes.

\begin{tabular}{llll}
\hline Pair & Group & Time period $\left(\mathrm{T}_{0}-\mathrm{T}_{1}\right)$ & Outcome at $\mathrm{T}_{1}$ \\
\hline 1 & MLC & Sep. 1998 - Jun. 2003 & Cohesion \\
& RCD & Aug. 1998 - May 1999 & Fragmentation (Wamba's RCD-K/ML) \\
2 & RCD & Jun. 1999 - Oct. 2000 & Cohesion with takeover (Onusumba) \\
& & Nov. 2000 - Jun. 2003 & Cohesion with takeover (Ruberwa) \\
& RCD-K/ML & Jun. 1999 - Jun. 2000 & Fragmentation (Lumbala's RCD-N) \\
& & Jun. - Nov. 2000 & Cohesion with takeover (Mbusa) \\
& & Dec. 2000 - Aug. 2002 & Fragmentation (Lubanga's UPC) \\
3 & RCD-K/ML & Sep. 2002 - Jun. 2003 & Cohesion \\
& UPC & Sep. 2002 - Mar. 2003 & Fragmentation (Kahwa's PUSIC) \\
& & Sep. 2002 - Mar. 2003 & Fragmentation (Kakwavu's FAPC) \\
\hline
\end{tabular}

The three comparisons are 'controlled' ${ }^{32}$ only in the sense of providing variation in the outcome. The underlying idea is that a sound theory of rebel fragmentation should be able to explain not only why a group experienced fragmentation but also why another group did not.

\footnotetext{
${ }^{31}$ Sidney G. Tarrow, 'The Strategy of Paired Comparison: Toward a Theory of Practice', Comparative Political Studies 43/2 (2010) 230-59.

32 Dan Slater and Daniel Ziblatt, 'The Enduring Indispensability of the Controlled Comparison', Comparative Political Studies 46/10 (2013) 1301-27.
} 
The cohesive group thus serves as a 'control observation'. ${ }^{33}$ By ensuring that a theoretically stipulated cause of fragmentation was both present in the fragmented group and absent in the cohesive group, paired comparisons help produce more robust causal inferences.

\section{MLC (1998-2003) vis-à-vis RCD (1998-9)}

According to Thomas Luhaka, a founding member of the RCD who later defected from the RCD-K/ML to the MLC, there was a major difference in how the RCD and the MLC interacted with their foreign sponsors. The RCD's senior officials were in regular contact with senior Rwandan and Ugandan officials, 'people one knew and could call'. By contrast, 'MLC cadres had no contact with Ugandan officials. It was Bemba alone who dealt with them.' The MLC, Luhaka came to realise, was essentially 'an alliance between Jean-Pierre Bemba and [Ugandan President Yoweri] Museveni'. ${ }^{34}$ The following subsections show how this enabled Bemba to reinforce his leadership and maintain organisational cohesion throughout the war, whereas the RCD broke apart in May 1999 due to an internal rivalry that was fuelled by the emerging rivalry between its two state sponsors.

\section{MLC, Sep. 1998 - Jun. 2003: Cohesion}

When the RCD launched the Second Congo War in August 1998, Bemba - the son of one of the most influential businessmen during Mobutu's rule - left his exile in Brussels to get involved in the fight against President Laurent Kabila. Following a series of meetings, he decided to ignore Rwandan Vice-President Paul Kagame's suggestion to join the RCD. ${ }^{35}$ According to Bemba's autobiography, he had concerns about the RCD's political vision and its military reliance on Rwanda. Instead, he asked Ugandan President Museveni to help him 'create a real alternative force to Kinshasa's dictatorial regime'. ${ }^{36}$ Museveni agreed, seeing an opportunity to 'develop a Congo policy distinct from that of Rwanda' ${ }^{37}$

Although officially founded on 30 September 1998, the MLC announced its existence only in November, after one month of military training by the Ugandan army in a camp near Kisangani in north-eastern Congo. Initially with heavy Ugandan military support, the MLC then routed Chadian and Congolese troops and seized nearly all of Equateur Province north of the

\footnotetext{
33 Jason Lyall, 'Process Tracing, Causal Inference, and Civil War', in Andrew Bennett and Jeffrey T. Checkel, eds., Process Tracing: From Metaphor to Analytic Tool (Cambridge: Cambridge University Press 2015), 192.

${ }^{34}$ Interview with Thomas Luhaka, Kinshasa, 23 July 2014 (my translation from French).

${ }^{35}$ Interview with Tito Rutaremara (RPF parliamentary leader, 1994-2000), Kigali, 12 August 2011.

${ }^{36}$ Jean-Pierre Bemba, Le choix de la Liberté (Gbadolite: Editions Vénus 2001), 10 (my translation).

${ }^{37}$ Reyntjens, The Great African War, 243.
} 
Congo River, culminating in the capture of Gbadolite - Mobutu's home town - in July 1999, where the group set up its headquarters. ${ }^{38}$ By that point, Bemba was firmly in control of the group's military actions, but 'the Ugandans continued to provide military support, in particular through artillery, training, and logistics' 39

Besides regional status concerns, one of Museveni's principal interests in sponsoring the MLC was to establish 'a safe backyard' 40 that would shield the country from attacks by Ugandan rebels who had external bases in Congo and received support from Sudan's government, Uganda's main foe at the time. ${ }^{41}$ Uganda therefore needed a strong and reliable Congolese partner. ${ }^{42}$ By consistently supporting Bemba and dealing with him directly, the Ugandans reinforced his relative power within the MLC. Dominique Kanku, formally in charge of the MLC's foreign affairs from 1999 to 2001, confirmed Luhaka's characterisation of the relationship with the Ugandans: 'Jean-Pierre controlled everything', always liaising alone with Museveni and other foreign presidents. ${ }^{43}$

Uganda's exclusive allocation of resources to Bemba contributed significantly to the MLC's cohesion because it prevented internal rivals from challenging him. That there was no shortage of latent rivalries became clear once the rebel group turned into a political party and joined the transitional government. Between 2003 and 2006, several of its senior officials defected to President Joseph Kabila's side. ${ }^{44}$ 'Opportunism', Stearns concludes, 'once a centripetal force in the MLC, had now burst the seams of the movement, flinging members in all directions. $^{45}$

\section{RCD, Aug. 1998 - May 1999: Fragmentation (Wamba's RCD-K/ML)}

The Second Congo War began on 2 August 1998 with a Rwandan-backed mutiny by the Congolese army's 10th Brigade stationed in Goma, the capital of North Kivu Province. At that time, many of the RCD's future political leaders had not even met, indicating Rwanda's prioritisation of military matters. ${ }^{46}$ The leaders' first meeting, in Kigali on 4 August, brought

\footnotetext{
38 Tatiana Carayannis, 'Elections in the DRC: The Bemba Surprise', Washington, DC, February 2008, 3-7.

${ }^{39}$ Stearns, Dancing in the Glory of Monsters, 225.

${ }^{40}$ Interview with Gen. Jeje Odongo (Uganda's Commander of the Army, 1998-2001), Kampala, 7 March 2012.

${ }^{41}$ Henning Tamm, 'The Origins of Transnational Alliances: Rulers, Rebels, and Political Survival in the Congo Wars', International Security 41/1 (2016) 147-81, 173-75.

${ }^{42}$ Interview with Odongo.

${ }^{43}$ Interview with Dominique Kanku, Kinshasa, 28 July 2014.

${ }^{44}$ Mehdi Belaid, Le Mouvement de Libération du Congo en RDC: De la guérilla au parti politique (Paris: L'Harmattan 2008), 148-57.

${ }^{45}$ Stearns, Dancing in the Glory of Monsters, 233.

${ }^{46}$ Roessler and Verhoeven, Why Comrades Go To War, 361-62.
} 
together 'people who had nothing in common', according to one of the group's future presidents. ${ }^{47}$ The reason for this paradox was simple: Rwandan officials and a group of Congolese Tutsi that had fallen out with President Laurent Kabila were trying to bring together as many individuals from Congo's elite opposed to Kabila as possible. ${ }^{48}$

The Rwandans helped install Ernest Wamba dia Wamba, a US-educated and internationally respected history and philosophy professor, as the RCD's figurehead, but they soon came to regret their decision. ${ }^{49}$ Instead of consistently backing Wamba, the Rwandans worked directly with Congolese Tutsi and with the RCD's military chief of staff, Jean-Pierre Ondekane, previously the 10th Brigade's commander.

'Not only did the RCD President have no substantive power,' Wamba complained in a statement issued shortly after the May 1999 split, 'he was continuously suffocated; he was given no necessary means for proper functioning. ${ }^{50}$ Most importantly, Wamba lacked control over military resources, as the RCD's military was commanded by Rwandan officers and its budget controlled by Rwanda's government. ${ }^{51}$ By dealing directly with Ondekane and his troops, the Rwandans thus ensured that Wamba had 'no material autonomy' ${ }^{52}$ Their approach reflected the RPF's centralist and militarist organisational culture. ${ }^{53}$

Nonetheless, Wamba managed to benefit from the emerging rivalry between Rwanda and Uganda. Amidst dissent within the RCD in March 1999, Wamba moved his base from Goma to Kisangani, where the Ugandan army's operational headquarters was located, and replaced his Rwandan bodyguards with Ugandan soldiers. ${ }^{54}$ In response, the RCD's pro-Rwanda wing convened a series of meetings in Goma from 16 to 20 May 1999, first dissolving the group's leadership, then appointing Emile Ilunga - another figurehead - as new RCD president. ${ }^{55}$ Wamba's internal rivals were led by vice-president Moïse Nyarugabo, foreign minister Bizima

\footnotetext{
${ }^{47}$ Interview with Emile Ilunga, Kinshasa, 19 August 2014 (my translation).

${ }^{48}$ Interviews with Ilunga; Jean-Baptiste Sondji (Congolese Minister of Health and Social Affairs, 1997-99), Kinshasa, 9 July 2011; and Moïse Nyarugabo (RCD vice-president, 1998-2000), Kinshasa, 18 August 2014.

49 Interview with Rutaremara.

${ }^{50}$ Ernest Wamba dia Wamba, 'Crisis in the Congolese Rally for Democracy (RCD): Struggle of antagonist political lines', June 1999 (copy obtained from the Royal Museum for Central Africa, Tervuren, Belgium).

${ }^{51}$ Stearns, Dancing in the Glory of Monsters, 209.

${ }^{52}$ Interview with Ernest Wamba dia Wamba, Kinshasa, 4 July 2011.

${ }^{53}$ Filip Reyntjens, Political Governance in Post-Genocide Rwanda (Cambridge: Cambridge University Press 2013), 7, 21, 81 .

${ }^{54}$ Interview with Wamba.

${ }^{55}$ Interview with Patrick Mazimhaka (Minister in the Office of the Rwandan President in 1999 and present at these meetings), Kigali, 9 May 2014; Integrated Regional Information Networks (IRIN), 'Update no. 672 for Central and Eastern Africa' and 'Update no. 675 for Central and Eastern Africa', Nairobi, 17 and 20 May 1999 , http://www.africa.upenn.edu/Hornet/irin672.html and http://www.africa.upenn.edu/Hornet/irin52099b.html.
} 
Karaha, and other Congolese Tutsi who had been working closely with the Rwandan government since the first war. ${ }^{56}$

But Wamba, who had returned to Goma for these meetings, refused to step down. Afraid of a plot to assassinate him, he asked Uganda's government for help, which responded by sending a plane to Goma. Ugandan soldiers then brought Wamba to the airport, from where he was flown to Kisangani via Uganda. At the same time, RCD members in favour of Wamba left Goma by road together with Ugandan troops, eventually joining him in Kisangani. ${ }^{57}$ In my interviews, both sides emphasised that this organisational split would not have been possible without Uganda's military support for Wamba's faction, which somewhat balanced the distribution of power between the two rival wings. ${ }^{58}$

\section{RCD (1999-2003) vis-à-vis RCD-K/ML (1999-2002)}

The RCD(-Goma) experienced several individual defections and two non-violent takeovers during the remainder of the war, but it did not suffer another split. Alleged new splinters that appeared in the media under names such as RCD-Authentic, RCD-Congo, and RCD-Original were fabrications by defectors and had no sustained military presence on the ground. ${ }^{59}$ By contrast, Wamba's new group, the RCD-K/ML, saw both a minor split in June 2000 and a major one in April 2002, as well as a violent takeover in November 2000. This section explains how Rwanda prevented any further splintering of the RCD and how Uganda actively encouraged fragmentation in the case of the RCD-K/ML.

\section{RCD, Jun. 1999 - Oct. 2000: Cohesion with takeover (Onusumba)}

Similar to Wamba, the RCD's new president Ilunga initially received Rwanda's political support, but his independent decision-making powers were very limited. While Ilunga declined to discuss the specifics of his own appointment and resignation, he confirmed that he 'could not appoint ministers without the RPF's approval' ${ }^{60}$ In fact, Rwanda's ruling party set up the

\footnotetext{
${ }^{56}$ Wamba, 'Crisis'.

${ }^{57}$ Henning Tamm, 'Status Competition in Africa: Explaining the Rwandan-Ugandan Clashes in the Democratic Republic of Congo', African Affairs 118/472 (2019) 509-30, 522.

58 Interviews with Nyarugabo; Antipas Mbusa Nyamwisi, Kinshasa, 14 July 2011; and Azarias Ruberwa, Kinshasa, 2 August 2014.

${ }^{59}$ Interview with Azarias Ruberwa, Kinshasa, 2 August 2014; Gauthier de Villers, République démocratique du Congo: De la guerre aux élections - L'ascension de Joseph Kabila et la naissance de la Troisième République (janvier 2001-août 2008) (Tervuren: Institut africain 2009), 120-21. In line with the RCD's own interpretation (interviews with Nyarugabo and Ruberwa), I treat the case of Pacifique Masunzu as a military defection rather than an organisational split because he joined forces with an existing group. See Jason Stearns, Banyamulenge: Insurgency and Exclusion in the Mountains of South Kivu (London: Rift Valley Institute 2013), 26-27.

${ }^{60}$ Interview with Ilunga (my translation).
} 
RCD's leadership structure to mirror that of its own government. Even though Vice-President Kagame, a Tutsi, was the country's strongman, the titular president was Pasteur Bizimungu, a Hutu. ${ }^{61}$ In the case of the RCD, president Ilunga lacked a real power base within the organisation, while vice-president Nyarugabo, a Congolese Tutsi, represented the most influential ethnic group. ${ }^{62}$

In terms of military power, Rwanda exerted so much control that an intra-organisational challenge without its backing seemed futile. As the International Crisis Group reported:

From the beginning Kigali seconded its officers to the RCD command structure and centralised decision-making for military operations with its own general staff. Control of fuel, finances, heavy artillery and armoured vehicles is another guarantee that no large-scale military operation takes place without Rwandan approval. ${ }^{63}$

Founding member José Endundo, who later defected to the MLC, bluntly summarised that 'everything was decided in Kigali' ${ }^{64}$ This also explains why an outsider like Adolphe Onusumba could succeed Ilunga in October 2000. Onusumba, a Tetela hailing from the same territory in southern-central Kasai-Oriental Province as independence hero Patrice Lumumba, was neither a founding member of the RCD nor a known political entity: before his military training in Rwanda and a short stint as RCD foreign minister, he had worked as a physician in South Africa from 1994 to $1999 .{ }^{65}$ Vice-president Nyarugabo resigned together with Ilunga and was effectively replaced by Azarias Ruberwa, another Congolese Tutsi, who was named both secretary-general and coordinator of the executive, causing observers to call him the RCD's 'actual head'. ${ }^{66}$ Remarkably, in my interview with him, Ruberwa struggled to explain why Onusumba was chosen as president, eventually suggesting 'there was hope' that the relatively youthful Onusumba could 'refresh' the group with 'new ideas'. ${ }^{67}$ The International Crisis Group more convincingly argued that Rwanda 'tired' of Ilunga's ineffective leadership and appointed Onusumba 'to use Lumumba's legacy to rally support for the RCD-Goma in the Kasais', just like MLC president Bemba had built on Mobutu's popularity in northern Congo. ${ }^{68}$

\footnotetext{
${ }^{61}$ Reyntjens, Political Governance, 80.

${ }^{62}$ De Villers et al., Guerre et politique, 70.

${ }^{63}$ ICG, 'The Kivus: The Forgotten Crucible of the Congo Conflict', Nairobi/Brussels, 24 January 2003, 10-11.

${ }^{64}$ Interview with José Endundo, Kinshasa, 31 August 2012 (my translation).

${ }^{65}$ Jean Omasombo, République démocratique du Congo: Biographies des acteurs de la Troisième République (Tervuren: Royal Museum for Central Africa 2009), 261.

${ }^{66}$ IRIN, 'DRC: Rebel Leader Resigns Admitting "Errors"', Nairobi, 30 October 2000, https://reliefweb.int/report/democratic-republic-congo/drc-rebel-leader-resigns-admitting-errors; de Villers et al., Guerre et politique, 75 (my translation).

${ }^{67}$ Interview with Ruberwa (my translation).

${ }^{68}$ ICG, 'Scramble for the Congo', 23, 28. Mazimhaka, the Rwandan president's point man on the RCD, indeed told me that Ilunga 'was not an effective leader' (interview).
} 


\section{RCD, Nov. 2000 - Jun. 2003: Cohesion with takeover (Ruberwa)}

Despite serving as the RCD's president for two and a half years, Onusumba did little to distinguish himself. ${ }^{69}$ It was primarily secretary-general Ruberwa who led the RCD's delegation during the peace process, which picked up speed after Laurent Kabila's assassination and replacement with his son, Joseph, in January 2001, and it was Ruberwa whom the RCD eventually nominated to be one of Congo's four vice-presidents during the transition that was to begin in July 2003. Observers noted that Rwanda deemed Ruberwa 'more dependable' than Onusumba. ${ }^{70}$ It therefore came as no surprise that, on 16 June 2003 , the RCD chose to replace Onusumba with Ruberwa, finally putting a Congolese Tutsi formally in charge. ${ }^{71}$ For Ruberwa, this was simply 'a matter of coherence': the rebel-group-turned-political-party's official soon to hold the most senior government rank also needed to occupy the party's most senior position. $^{72}$

Since many observers saw Ruberwa as the RCD's real leader from November 2000 onwards, it is important to stress that Rwanda did use its resources to keep Onusumba in power until June 2003. For example, the RCD's military leadership was unhappy with Onusumba's financial management and tried to overthrow him in August 2002, forcing Rwanda to intervene on his behalf. ${ }^{73}$ Ruberwa confirmed that Rwandan officials convinced the coup plotters to reconcile with Onusumba. ${ }^{74}$ This episode illustrates that internal rivals did not consider a sustained armed challenge against the existing leader to be viable unless it was backed by the group's state sponsor. By contrast, defecting to another rebel group or to the Congolese government was a far more promising option.

\section{RCD-K/ML, Jun. 1999 - Jun. 2000: Fragmentation (Lumbala's RCD-N)}

Clashes between Rwandan and Ugandan troops in Kisangani in August 1999 forced the RCD$\mathrm{K} / \mathrm{ML}$ to transfer its headquarters to Bunia, the capital of Ituri District in north-eastern Orientale Province. In October 1999, RCD-K/ML president Wamba announced the formation of a 'government' that was nominally in control of Kibali-Ituri and Beni-Lubero, two newly created provinces which combined parts of Orientale and North Kivu and which were both occupied

\footnotetext{
${ }^{69}$ On internal criticism against Onusumba, see de Villers, De la guerre aux élections, 131 (note 42), 135.

${ }^{70}$ IRIN, 'DRC: Wrangling Hits Dialogue again over Leadership Roles', Sun City/Nairobi, 16 April 2002, https://reliefweb.int/report/democratic-republic-congo/drc-wrangling-hits-dialogue-again-over-leadership-roles.

${ }^{71}$ De Villers, De la guerre aux élections, 155.

${ }^{72}$ Interview with Ruberwa (my translation).

${ }^{73}$ ICG, 'The Kivus', 18.

${ }^{74}$ Interview with Ruberwa.
} 
by allied Ugandan troops. ${ }^{75}$ From the outset, Wamba's control over the RCD-K/ML 'was loose' and the group 'was riven by suborganizational rivalries'. ${ }^{76}$ In June 2000, in the midst of the leadership struggle covered in the next subsection, Roger Lumbala, a Luba from southern Congo, managed to form a breakaway group in Bafwasende, a town in a mineral-rich area of north-eastern Congo, where he had no pre-war power base. ${ }^{77}$

Lumbala was a founding member of the RCD and served as its mobilisation and propaganda minister. He defected from the RCD in February 2000, joined the RCD-K/ML, and then swiftly exploited his deployment as mobilisation officer to Bafwasende, creating the RCD-N out of the RCD-K/ML military units stationed there. ${ }^{78}$ According to both MLC leader Bemba and one of his commanders, Lumbala benefited from Ugandan operational commander James Kazini's protection and arrived in Bafwasende via Ugandan aircraft. ${ }^{79}$ Lumbala also used his Ugandan connections to exploit the area's small diamond mines, later calling himself 'a good warlord' ${ }^{80}$

In short, Lumbala was able to create the RCD-N by utilising the 'military entrepreneurialism' of Ugandan army officers. ${ }^{81}$ 'It was only for business, all for business, nothing else - no ideology at all', the RCD-K/ML's former security minister concurred. ${ }^{82}$ Paradoxically, the Ugandans encouraged Lumbala - an internal rival - to break away from the RCD-K/ML while simultaneously maintaining their support for the group's existing leadership. This seemingly contradictory division of Ugandan resources was in fact simply one of the many 'paradoxes of the Museveni regime': while Museveni supported Wamba, he had to allow Kazini and other officers to work with Lumbala in order to satisfy 'the army's need for new sources of patronage' and thus ensure his own political survival. ${ }^{83}$

\footnotetext{
${ }^{75}$ De Villers et al., Guerre et politique, 78-86.

${ }^{76}$ Prunier, Africa's World War, 229.

${ }^{77}$ Omasombo, Troisième République, 154.

${ }^{78}$ IRIN, 'Update No. 1042 for the Great Lakes', Nairobi, 30 October 2000, http://reliefweb.int/report/burundi/irinupdate-1042-great-lakes; Human Rights Watch (HRW), 'Uganda in Eastern DRC: Fueling Political and Ethnic Strife', March 2001, 23-24.

${ }^{79}$ Bemba, Le choix de la Liberté, 159; Belaid, Le Mouvement, 77.

${ }^{80}$ Quoted in Prunier, Africa's World War, 431 (note 5).

${ }^{81}$ Koen Vlassenroot, Sandrine Perrot, and Jeroen Cuvelier, 'Doing Business Out of War: An Analysis of the UPDF's Presence in the Democratic Republic of Congo', Journal of Eastern African Studies 6/1 (2012) 2-21, 3. ${ }^{82}$ Interview with Esdras Kambale Bahekwa, Kinshasa, 2 August 2014.

${ }^{83}$ Aili Mari Tripp, Museveni's Uganda: Paradoxes of Power in a Hybrid Regime (Boulder, CO: Lynne Rienner 2010), 6, 4 .
} 


\section{RCD-K/ML, Jun. - Nov. 2000: Cohesion with takeover (Mbusa)}

At the time of the RCD-N split, RCD-K/ML president Wamba was preoccupied with a more direct challenge to his leadership. Antipas Mbusa Nyamwisi, the group's commissioner-general, and John Tibasima, Mbusa's deputy, repeatedly tried to overthrow Wamba, eventually succeeding in November 2000. Whereas Wamba was an ethno-regional outsider in north-eastern Congo, Mbusa and Tibasima had strong local power bases. Mbusa is a Nande, whose traders have long played a key role in Beni-Lubero's regional economy. ${ }^{84}$ Tibasima is a Hema, whose socio-economic dominance over Ituri's other ethnic groups dates back at least to the Belgian colonial period. ${ }^{85}$

Uganda played a critical role in the infighting lasting from March to November 2000, a period that Human Rights Watch called 'the constant coup d'état'. ${ }^{86}$ The RCD-K/ML's sponsor was at times itself internally divided: some Ugandan officers on the ground supported the local strongmen Mbusa and Tibasima, repeatedly forcing President Museveni to intervene on Wamba's behalf. When troops loyal to Mbusa surrounded Wamba's residence in Bunia in November, however, Museveni finally gave up on the embattled professor. ${ }^{87}$ Museveni's decision united Ugandan resources behind Mbusa, guaranteeing his coup's success. Wamba was flown to Kampala and then, after disagreeing with Uganda's creation of the FLC, advised to move to Tanzania, ending his involvement in the armed struggle. ${ }^{88}$ At the time, Ugandan officials privately admitted to the International Crisis Group 'that given [Mbusa] Nyamwisi's ethnic support and economic power in Province Orientale, it is wise to have him head the rebellion'. ${ }^{89}$

\section{RCD-K/ML, Dec. 2000 - Aug. 2002: Fragmentation (Lubanga's UPC)}

Over the next year and a half, the RCD-K/ML's new leader Mbusa played an increasingly complicated game of alliances. When Uganda created the FLC in January 2001 as an umbrella for its Congolese rebel allies, it appointed Bemba as president, effectively putting the RCDK/ML's provinces under his control. This angered Nande and Hema elites, who saw Bemba as yet another ethno-regional outsider trying to rule them. ${ }^{90}$ For Mbusa, Bemba's appointment

\footnotetext{
84 Timothy Raeymaekers, 'The Political Economy of Beni-Lubero', in Koen Vlassenroot and Timothy Raeymaekers, eds., Conflict and Social Transformation in Eastern DR Congo (Gent: Academia Press 2004).

${ }^{85}$ Dan Fahey, Ituri: Gold, Land, and Ethnicity in North-Eastern Congo (London: Rift Valley Institute 2013).

${ }^{86} \mathrm{HRW}$, 'Uganda in Eastern DRC', 17.

${ }^{87}$ Henning Tamm, UPC in Ituri: The External Militarization of Local Politics in North-Eastern Congo (London: Rift Valley Institute 2013), 17-21.

${ }^{88}$ Interview with Wamba.

${ }^{89} \mathrm{ICG}$, 'Scramble for the Congo', 36.

${ }^{90}$ De Villers, De la guerre aux élections, 123-25.
} 
also signalled that Ugandan President Museveni had enough of his 'autonomist spirit'. ${ }^{91} \mathrm{He}$ thus went into exile in South Africa, from where he began not only to scheme against Bemba but also to initiate an alliance with Congo's new president Joseph Kabila. Realizing that the peace process was about to gather steam, Mbusa 'bet on becoming Kinshasa's man in the northeast' ${ }^{92}$

At the same time, Mbusa used his relationships with corruptible Ugandan army officers and with Hema elites within the RCD-K/ML to oust Bemba's MLC first from Beni in June and then from Bunia in November 2001. After these victories, however, tensions emerged between Mbusa's representatives and Thomas Lubanga, the RCD-K/ML's newly appointed minister of defence. Lubanga had usurped Tibasima's role as the Hema representative with the biggest influence over the group's armed forces. ${ }^{93}$ The tensions escalated in April 2002, when Lubanga co-signed a political declaration that accused Mbusa of ethnic discrimination and of selling out Ituri at the peace talks. Within days, troops loyal to Lubanga mutinied, seizing partial control of Bunia. ${ }^{94}$

At the time of the mutiny, the Ugandan army had at least one battalion stationed in Bunia. ${ }^{95}$ It was the Ugandan soldiers' inaction that enabled the mutiny, and it was their active involvement four months later - helping Lubanga's mutineers, who came to be known as UPC, to oust Mbusa's faction from Bunia - that consummated the organisational split. ${ }^{96}$ Daniel Litsha, the UPC's first secretary-general, interpreted Uganda's involvement in August as a message to the Congolese government that it could set foot in Mbusa's stronghold Beni-Lubero but not in Ituri. ${ }^{97}$ Put differently, the RCD-K/ML's fragmentation was a result of divided external resources, with Kinshasa supporting the existing leader and Kampala backing his internal rival.

\section{RCD-K/ML (2002-3) vis-à-vis UPC (2002-3)}

Following the split in August 2002, Mbusa's RCD-K/ML lost a significant share of its territory, but it did not experience any further fragmentation for the rest of the war. By contrast,

\footnotetext{
${ }^{91}$ Interview with Mbusa (my translation).

92 Gérard Prunier, "The "Ethnic" Conflict in Ituri District: Overlapping of Local and International in CongoKinshasa', in Jean-Pierre Chrétien and Richard Banégas, eds., The Recurring Great Lakes Crisis: Identity, Violence and Power (London: Hurst \& Co. 2008), 192.

93 Tamm, UPC in Ituri, 19-23.

94 International Criminal Court (ICC), 'Situation in the Democratic Republic of the Congo in the Case of the Prosecutor v. Thomas Lubanga Dyilo: Judgment pursuant to Article 74 of the Statute', The Hague, 14 March 2012, paras. 1089-97.

${ }^{95}$ UNSC, 'Twelfth Report', para. 8.

96 Tamm, UPC in Ituri, 25-26.

${ }^{97}$ Interview with Daniel Litsha, Bunia, 8 August 2012.
} 
Lubanga's UPC suffered two splits, losing control over Bunia and large parts of Ituri in the process. This section discusses how Mbusa's alliance with the Congolese government helped him maintain the RCD-K/ML's cohesion, whereas Lubanga's decision to accept Rwandan support led Uganda to back his internal rivals and break the UPC apart.

\section{RCD-K/ML, Sep. 2002 - Jun. 2003: Cohesion}

Having lost most of its Hema members to the UPC and been forced out of Bunia, the RCD$\mathrm{K} / \mathrm{ML}$ retreated to Mbusa's home region, Beni-Lubero. Even there, however, Mbusa 'barely managed to control the towns of Beni and Butembo, whose inhabitants were becoming increasingly prone to internal rivalries. ${ }^{98}$ After Mbusa signed the Sun City peace agreement in April 2002, 'Beni-Lubero's countryside completely returned to the control of competing Mayi-Mayi militias, some of whom took up the role of private security guards for Butembo's local businessmen. ${ }^{99}$ Despite this very poor governance record, Mbusa managed to cling on to power and prevent further splits. Why?

According to an RCD-K/ML representative, the Congolese government's backing of Mbusa reduced internal dissent: former critics began to acknowledge him as the 'sole master' ${ }^{100}$ Kinshasa provided the RCD-K/ML 'with uniforms, ammunition, and trainers' ${ }^{101}$ It also set up a military command centre in Beni, sending army soldiers to support Mbusa's troops. ${ }^{102}$ In short, the government consistently united its resources behind Mbusa, thus reinforcing his relative power within the group.

Mbusa's alliance with the Congolese government may have also had a more indirect effect that reinforced cohesion even as it threatened the group's very existence. RCD-K/ML cadres argued that the military offensives launched against the group by the MLC and the RCD-N in the north and by the RCD in the south created a siege mentality that united the Beni-Lubero region behind Mbusa. ${ }^{103}$

\footnotetext{
${ }^{98}$ Raeymaekers, 'The Political Economy of Beni-Lubero', 67.

${ }^{99}$ Ibid.

${ }^{100}$ Interview with Nelson Paluku (a long-term political ally of the Nyamwisi family who joined the RCD-K/ML after the war and took up Mbusa's parliamentary seat in 2013), Kinshasa, 27 July 2014 (my translation). On the other hand, Raeymaekers (ibid.) claims that 'Nyamwisi's opportunistic shift to Kinshasa also led to growing discontent from RCD-ML leaders'.

${ }^{101}$ HRW, 'Ituri: “Covered in Blood”. Ethnically Targeted Violence in Northeastern DR Congo', July 2003, 9.

102 Ibid.; Raeymaekers, 'The Political Economy of Beni-Lubero', 77 (note 22).

${ }^{103}$ Interviews with Paluku; Eric Kamavu (the RCD-K/ML's mayor of Butembo from 2001 to 2003, then its Benibased provincial governor in 2003), Kinshasa, 31 July 2014.
} 


\section{UPC, Sep. 2002 - Mar. 2003: Fragmentation (Kahwa's PUSIC)}

Up to September 2002, the inter-ethnic conflict between Hema and Lendu in Ituri and the intraRCD-K/ML conflict between Hema and Nande had largely overshadowed the fact that the Hema themselves were far from homogenous. The UPC was dominated by northern Hema such as Lubanga. ${ }^{104}$ This caused resentment among southern Hema, represented by the group's deputy minister of defence Yves Kahwa, who felt that the UPC did not provide them with enough protection against Lendu attacks. Fearful of a rumoured assassination plot, Kahwa fled to Uganda in December 2002. Following negotiations with President Museveni and with Congolese President Kabila, with whom Museveni had in the meantime concluded an agreement to normalise relations, Kahwa then created the PUSIC. ${ }^{105}$

The group at first existed only on paper (as a political party), but it became a reality during the March 2003 battle for Bunia between the Ugandan army and the now Rwandan-backed UPC, when Kahwa called UPC commanders loyal to him and convinced them to defect to his side. ${ }^{106}$ Kahwa is a customary chief of the Bahema Banywagi chefferie, which lies on the border separating northern and southern Hema but identifies with the latter. PUSIC's founding spokesperson Augustin Kisembo Bitamara is a customary chief of the Bahema Sud chefferie. It was primarily fighters from these two chieftaincies who defected from the UPC to the PUSIC in March 2003. ${ }^{107}$

The UPC's relations with Uganda had been ambiguous from the start. Facing international pressure to withdraw from Congo, Uganda was trying to hold on to Ituri while simultaneously demonstrating its good will towards the Congolese government. In June 2002, Uganda detained UPC leader Lubanga, who proved stubborn in negotiations over Bunia's divided status, and sent him to Kinshasa, where he was put under house arrest. Feeling betrayed, the UPC responded by initiating a secret alliance with Rwanda, Uganda's main rival at the time. When Uganda paradoxically helped the UPC take over Bunia two months later, the group was already receiving covert military assistance from Rwanda. Uganda soon found out and, itself feeling betrayed, sought to undermine UPC leader Lubanga, who by then had returned to Bunia and reinforced the group's alliance with Rwanda. As Kahwa, Lubanga's internal rival, feared for his life in December 2002, it was Uganda that sent a plane to evacuate him from Bunia. ${ }^{108}$

\footnotetext{
104 HRW, 'Ituri: “Covered in Blood", 21; Koen Vlassenroot and Timothy Raeymaekers, 'The Politics of Rebellion and Intervention in Ituri: The Emergence of a New Political Complex?', African Affairs 103/412 (2004) 385-412, 396.

105 Tamm, UPC in Ituri, 35-36.

${ }^{106}$ Ibid., 36-37.

${ }^{107}$ Email correspondence with a former PUSIC official, August 2014.

${ }^{108}$ HRW, 'Ituri: "Covered in Blood"', 17; Tamm, UPC in Ituri, 35-36.
} 
Divided external resources subsequently proved key to the split in March 2003: while Rwanda stood firmly behind Lubanga, Kahwa was able to tell his loyalists that the Ugandan army would protect them if they defected to his side. ${ }^{109}$

\section{UPC, Sep. 2002 - Mar. 2003: Fragmentation (Kakwavu's FAPC)}

Two days prior to the battle for Bunia in March 2003, the UPC suffered another split, also supported by Uganda to retaliate against Lubanga's alliance with Rwanda. Jérôme Kakwavu, a Congolese Tutsi commander who had defected from Mbusa's RCD-K/ML to the UPC around November 2002 and then controlled Ituri's northern Aru and Mahagi territories for the UPC, broke away with roughly 1,500 fighters to form the FAPC. ${ }^{110}$

According to UPC secretary-general Litsha, Uganda threatened Kakwavu, telling him that he could either launch an anti-Lubanga splinter group and receive the Ugandan army's support or remain loyal to Lubanga and face a Ugandan attack. ${ }^{111}$ Unsurprisingly, Kakwavu chose the splinter option: Aru town is located just a few miles from the Ugandan border, which meant that siding with Lubanga and Rwanda would have left him extremely vulnerable. By March 2003, most Rwandan troops had been withdrawn from Congo; Rwanda's support to Lubanga consisted mostly of training, uniforms, and weapons. ${ }^{112}$ The Ugandan army subsequently delivered on its promise to Kakwavu, for instance by sending troops across the border to crush an internal FAPC revolt against him in May 2003. ${ }^{113}$

\section{Conclusion}

The ten organisational outcomes from the Second Congo War analysed in this article show how strongly external troops can influence internal rebel group dynamics. By sending troops to fight alongside foreign rebels, state sponsors can strengthen an existing leader, help replace him with an internal rival, or encourage a rival to form a splinter group. When the distribution of power between the leader and the rival hangs in the balance due to external troop support on both sides, fragmentation becomes the most likely outcome. Such a perspective on organisational outcomes may make it sound as though direct military intervention on the side of rebel

\footnotetext{
${ }^{109}$ Kahwa also received financial support from the Congolese government at the time of the split. Interviews with former PUSIC officials, Bunia and Kinshasa, August 2012.

110 Omasombo, Troisième République, 76; Kristof Titeca, 'Access to Resources and Predictability in Armed Rebellion: The FAPC's Short-lived “Monaco” in Eastern Congo', Africa Spectrum 62/2 (2011) 43-70, 49; Tamm, UPC in Ituri, 36-37.

${ }^{111}$ Interview with Daniel Litsha, Bunia, 10 August 2012. See also ICG, 'Congo Crisis: Military Intervention in Ituri', Nairobi/New York/Brussels, 14 June 2003, 10.

112 ICC, 'Lubanga Judgment', para. 554.

${ }^{113}$ HRW, 'The Curse of Gold: Democratic Republic of Congo', 2 June 2005, 89.
} 
groups simply turned them into puppets of foreign forces. But a closer look at the five organisational splits suggests otherwise; it highlights the agency of rebel leaders and their rivals. Four of the splits were caused by the decision of leaders to turn away from one state sponsor and toward a rival state that they deemed more useful: Wamba turned from Rwanda to Uganda (resulting in the RCD-K/ML), Mbusa turned from Uganda to the Congolese government (leading to the UPC), and Lubanga turned from Uganda to Rwanda (resulting in the PUSIC and FAPC). In the fifth case, it was not just the military entrepreneurialism of Ugandan officers but also the internal rival Lumbala's own entrepreneurialism that led to the RCD-N.

The fine-grained evidence from the war also shows how exactly state sponsors can allocate their resources to enable organisational splits. In three of the five splits, Uganda used its airplanes to transport the instigator of the split to their new rebel base (Wamba and Lumbala were flown to Kisangani and Bafwasende, respectively) and/or away from imminent danger (Wamba and Kahwa were airlifted out of Goma and Bunia, respectively, as they faced assassination plots). In the other two splits, it was the presence (or proximity) and the active support of Ugandan troops (or the threat thereof) that enabled Lubanga and Kakwavu to form splinters. Remarkably, despite the involvement of three different states - Rwanda, Uganda, and Congo - it was always Uganda that backed the splinter. This led many former Congolese rebels I interviewed to accuse the Ugandans of a deliberate divide-and-rule strategy.

Several cases also highlight that state sponsors can promote individuals who otherwise would not have been likely to lead a rebel group. The historian Wamba, who hailed from western Congo, was an unlikely leader of a mutiny-turned-rebellion that began in eastern Congo, just as Onusumba, a medical doctor who had only just finished a few months of military training abroad, was an unlikely new leader of the rebellion that by then comprised more than 15,000 battle-hardened fighters. ${ }^{114}$ Regarding the post-1999 splinter groups, Lumbala stands out as the least likely leader: in contrast to Lubanga, Kahwa, and Kakwavu, he started a rebel group in a resource-rich region in which he had spent barely any time beforehand. By his own account, the RCD-N started out with merely seventy fighters. ${ }^{115}$ Observers joked that he did not have 'a military front but rather a mining front'. ${ }^{116}$ Without the helping hand of Ugandan officers, Lumbala would have likely been pushed aside by a local strongman.

According to information collected by the Uppsala Data Conflict Program, rebel groups that receive external troop support are much less likely to split than those that receive non-

\footnotetext{
${ }^{114}$ ICG, 'Scramble for the Congo', 4.

115 Prunier, Africa's World War, 431 (note 5).

${ }^{116}$ Quoted in Omasombo, Troisième République, 154 (my translation).
} 
troop support. The RCD is one of the few larger groups that defies this trend. ${ }^{117}$ Future research on groups with external troop support should therefore primarily investigate whether it is the two patterns of external resource allocation hypothesised above to foster cohesion or cohesion with takeover that explain the cohesion of these groups: united and consistent or united but shifting sponsorship.

To return to the most prominent recent example, Russia's support to eastern Ukrainian separatists, suggestive evidence indeed confirms both patterns. In August 2014, Russia orchestrated an orderly takeover, replacing Donetsk People's Republic leader Alexander Borodai with Alexander Zakharchenko. ${ }^{118}$ Following this shift, the next year and a half saw consistent Russian sponsorship. The International Crisis Group reported that Moscow seemed 'to have thrown its weight behind the top leaders of both [separatist] entities', the Donetsk and Luhansk People's Republics (DNR and LNR), and that these leaders were 'widely believed to have stayed at the top thanks to extensive Russian support'. ${ }^{119}$ The similarities between Russia's intervention in eastern Ukraine and Rwanda's and Uganda's interventions in eastern Congo do not end there. Similar to Rwanda's involvement in the RCD's armed forces, for example, DNR and LNR units 'have been reorganised by Russian officers and subsumed into a formal military structure', with Russian officers in command and former local commanders as deputies. ${ }^{120}$

This state sponsor strategy of achieving rebel cohesion by using the sponsor's own troops to organise and control rebel forces is also evident in two of the other cases of large-scale troop support mentioned in the introduction. In 1970, North Vietnamese officials claimed to have helped the Khmer Rouge 'to systematize their doctrine, map out their policy lines, set up their organization, and draw up their plans of action.' ${ }^{121}$ The Ethiopian-based Western Somali Liberation Front and the Somali-Abo Liberation Front were 'both organizationally and logistically $\ldots$ in the grip of a foreign authority': especially during the 1977-78 Ogaden War, 'the fronts were ancillaries of the Somali army'. ${ }^{122}$

Clearly, then, despite all its complexity and certain unique characteristics, the Second Congo War provides insights into the strategies of state sponsors that can be profitably extended to other conflicts featuring significant external troop support for the rebel side.

\footnotetext{
117 See the discussion in Tamm, 'Rebel Leaders', 602.

118 Anton Zverev, 'Ex-Rebel Leaders Detail Role Played by Putin Aide in East Ukraine', Reuters, 11 May 2017, https://www.reuters.com/article/us-ukraine-crisis-russia-surkov-insight-idUSKBN1870TJ.

${ }_{119}$ ICG, 'Russia and the Separatists in Eastern Ukraine', Kyiv/Brussels, 5 February 2016, 4, 7.

120 Ibid., 8. See also Ivan Katchanovski, 'The Separatist War in Donbas: A Violent Break-up of Ukraine?' European Politics and Society 17/4 (2016) 473-489, 482-483.

${ }^{121}$ North Vietnamese document from April 1970, quoted in Morris, Why Vietnam Invaded Cambodia, 50.

${ }^{122}$ Gebru Tareke, The Ethiopian Revolution: War in the Horn of Africa (New Haven, CT: Yale University Press 2009), 188.
} 


\section{Notes on contributor}

Henning Tamm is a Lecturer in International Relations at the University of St Andrews. Previously, he was a Postdoctoral Prize Research Fellow at Nuffield College, University of Oxford, and a Predoctoral Fellow with the Program on Order, Conflict, and Violence at Yale University's MacMillan Center for International and Area Studies. He received his doctorate from the University of Oxford.

\section{Acknowledgments}

The author thanks Seamus Duggan, Ferdinand Eibl, Quint Hoekstra, Corinna Jentzsch, Zoe Marks, Lee Seymour, Duncan Snidal, and the anonymous reviewers for helpful comments on (much) earlier drafts. The interviews for this article were conducted while the author was based at St Antony's College and Nuffield College, Oxford. He gratefully acknowledges travel grants from the Cyril Foster Fund and the Alastair Buchan Subsidiary Fund of the Department of Politics and International Relations, the Peter Fitzpatrick Fund of St Antony's College, and the John Fell OUP Research Fund, all at the University of Oxford.

\section{Bibliography}

Ahmad, Aisha, 'Going Global: Islamist Competition in Contemporary Civil Wars', Security Studies 25/2 (2016) 353-84.

Bakke, Kristin M., 'Help Wanted? The Mixed Record of Foreign Fighters in Domestic Insurgencies', International Security 38/4 (2014) 150-87.

Bakke, Kristin M., Kathleen Gallagher Cunningham, and Lee J. M. Seymour, 'A Plague of Initials: Fragmentation, Cohesion, and Infighting in Civil Wars', Perspectives on Politics $10 / 2(2012) 265-83$.

Belaid, Mehdi, Le Mouvement de Libération du Congo en RDC: De la guérilla au parti politique (Paris: L'Harmattan 2008).

Bemba, Jean-Pierre, Le choix de la Liberté (Gbadolite: Editions Vénus 2001).

Berry, Jeffrey M., 'Validity and Reliability Issues In Elite Interviewing', PS: Political Science \& Politics 35/4 (2002) 679-82.

Bowen, Andrew S., 'Coercive Diplomacy and the Donbas: Explaining Russian Strategy in Eastern Ukraine', Journal of Strategic Studies 42/3-4 (2019) 312-43. 
Carayannis, Tatiana, 'Elections in the DRC: The Bemba Surprise', Washington, DC, February 2008.

Christia, Fotini, Alliance Formation in Civil Wars (Cambridge: Cambridge University Press 2012).

Cunningham, David E., Kristian Skrede Gleditsch, and Idean Salehyan, 'Non-State Actors in Civil Wars: A New Dataset', Conflict Management and Peace Science 30/5 (2013) 516-31.

Czuperski, Maksymilian, John Herbst, Eliot Higgins, Alina Polyakova, and Damon Wilson. 2015. 'Hiding in Plain Sight: Putin's War in Ukraine', Atlantic Council, Washington DC, May 2015.

De Villers, Gauthier, République démocratique du Congo: De la guerre aux élections L'ascension de Joseph Kabila et la naissance de la Troisième République (janvier 2001août 2008) (Tervuren: Institut africain 2009).

De Villers, Gauthier, Jean Omasombo, and Erik Kennes, République démocratique du Congo: Guerre et politique - Les trente derniers mois de L. D. Kabila (août 1998-janvier 2001) (Tervuren: Institut africain 2001).

De Waal, Thomas, Black Garden: Armenia and Azerbaijan through Peace and War (New York: New York University Press 2003).

Dowd, Caitriona, 'Actor Proliferation and the Fragmentation of Violent Groups in Conflict', Research and Politics 2/4 (2015) 1-7.

Fahey, Dan, Ituri: Gold, Land, and Ethnicity in North-Eastern Congo (London: Rift Valley Institute 2013).

Gates, Scott, 'Recruitment and Allegiance: The Microfoundations of Rebellion', Journal of Conflict Resolution 46/1 (2002) 111-30.

Hafez, Mohammed M., 'Fratricidal Rebels: Ideological Extremity and Warring Factionalism in Civil Wars', Terrorism and Political Violence, published online on 29 November 2017.

Human Rights Watch (HRW), 'The Curse of Gold: Democratic Republic of Congo', 2 June 2005.

HRW, 'Ituri: “Covered in Blood”. Ethnically Targeted Violence in Northeastern DR Congo', July 2003.

HRW, 'Uganda in Eastern DRC: Fueling Political and Ethnic Strife', March 2001.

Integrated Regional Information Networks (IRIN), 'DRC: Wrangling Hits Dialogue again over Leadership Roles', Sun City/Nairobi, 16 April 2002, https://reliefweb.int/report/democraticrepublic-congo/drc-wrangling-hits-dialogue-again-over-leadership-roles. 
IRIN, 'DRC: Rebel Leader Resigns Admitting "Errors"”, Nairobi, 30 October 2000, https://reliefweb.int/report/democratic-republic-congo/drc-rebel-leader-resigns-admittingerrors.

IRIN, 'Update No. 1042 for the Great Lakes', Nairobi, 30 October 2000, http://reliefweb.int/report/burundi/irin-update-1042-great-lakes.

IRIN, 'Update no. 675 for Central and Eastern Africa', Nairobi, 20 May 1999, http://www.africa.upenn.edu/Hornet/irin52099b.html.

IRIN, 'Update no. 672 for Central and Eastern Africa', Nairobi, 17 May 1999, http://www.africa.upenn.edu/Hornet/irin672.html.

International Criminal Court (ICC), 'Situation in the Democratic Republic of the Congo in the Case of the Prosecutor v. Thomas Lubanga Dyilo: Judgment pursuant to Article 74 of the Statute', The Hague, 14 March 2012.

International Crisis Group (ICG), 'Russia and the Separatists in Eastern Ukraine', Kyiv/Brussels, 5 February 2016.

ICG, 'Congo Crisis: Military Intervention in Ituri', Nairobi/New York/Brussels, 14 June 2003.

ICG, 'The Kivus: The Forgotten Crucible of the Congo Conflict', Nairobi/Brussels, 24 January 2003.

ICG, 'Scramble for the Congo: Anatomy of an Ugly War', Nairobi/Brussels, 20 December 2000 .

Johnston, Patrick, 'The Geography of Insurgent Organization and its Consequences for Civil Wars: Evidence from Liberia and Sierra Leone', Security Studies 17/1 (2008) 107-37.

Kalyvas, Stathis N., 'Ethnic Defection in Civil War', Comparative Political Studies 41/8 (2008) 1043-68.

Katchanovski, Ivan, 'The Separatist War in Donbas: A Violent Break-up of Ukraine?' European Politics and Society 17/4 (2016) 473-489.

Kenny, Paul D., 'Structural Integrity and Cohesion in Insurgent Organizations: Evidence from Protracted Conflicts in Ireland and Burma', International Studies Review 12/4 (2010) 53355.

Krause, Peter, 'The Structure of Success: How the Internal Distribution of Power Drives Armed Group Behavior and National Movement Effectiveness', International Security 38/3 (2013/14) 72-116.

Lidow, Nicholai Hart, Violent Order: Understanding Rebel Governance through Liberia's Civil War (New York: Cambridge University Press 2016). 
Lyall, Jason, 'Process Tracing, Causal Inference, and Civil War', in Andrew Bennett and Jeffrey T. Checkel, eds., Process Tracing: From Metaphor to Analytic Tool (Cambridge: Cambridge University Press 2015).

Morris, Stephen J., Why Vietnam Invaded Cambodia: Political Culture and the Causes of War (Stanford, CA: Stanford University Press 1999).

Mosinger, Eric S., 'Balance of Loyalties: Explaining Rebel Factional Struggles in the Nicaraguan Revolution', Security Studies 28/5 (2019) 935-75.

Nolutshungu, Sam C., Limits of Anarchy: Intervention and State Formation in Chad (Charlottesville, VA: University Press of Virginia 1996).

Nzongola-Ntalaja, Georges, The Congo from Leopold to Kabila: A People's History (London: Zed Books 2002).

Olson Lounsbery, Marie, 'Foreign Military Intervention, Power Dynamics, and Rebel Group Cohesion', Journal of Global Security Studies 1/2 (2016) 127-41.

Olson Lounsbery, Marie, and Alethia H. Cook, 'Rebellion, Mediation, and Group Change: An Empirical Investigation of Competing Hypotheses', Journal of Peace Research 48/1 (2011) 73-84.

Omasombo, Jean, République démocratique du Congo: Biographies des acteurs de la Troisième République (Tervuren: Royal Museum for Central Africa 2009).

Oppenheim, Ben, Abbey Steele, Juan F. Vargas, and Michael Weintraub, 'True Believers, Deserters, and Traitors: Who Leaves Insurgent Groups and Why', Journal of Conflict Resolution 59/5 (2015) 794-823.

Pearlman, Wendy, 'Spoiling Inside and Out: Internal Political Contestation and the Middle East Peace Process', International Security 33/3 (2008/9) 79-109.

Pearlman, Wendy, and Kathleen Gallagher Cunningham, 'Nonstate Actors, Fragmentation, and Conflict Processes', Journal of Conflict Resolution 56/1 (2012) 3-15.

Prunier, Gérard, Africa's World War: Congo, the Rwandan Genocide, and the Making of a Continental Catastrophe (New York: Oxford University Press 2009).

Prunier, Gérard, 'The "Ethnic" Conflict in Ituri District: Overlapping of Local and International in Congo-Kinshasa', in Jean-Pierre Chrétien and Richard Banégas, eds., The Recurring Great Lakes Crisis: Identity, Violence and Power (London: Hurst \& Co. 2008).

Raeymaekers, Timothy, 'The Political Economy of Beni-Lubero', in Koen Vlassenroot and Timothy Raeymaekers, eds., Conflict and Social Transformation in Eastern DR Congo (Gent: Academia Press 2004). 
Republic of Uganda, 'Judicial Commission of Inquiry into Allegations into Illegal Exploitation of Natural Resources and Other Forms of Wealth in the Democratic Republic of Congo 2001 (May 2001 - June 2002): Transcript', June 2002.

Reyntjens, Filip, Political Governance in Post-Genocide Rwanda (Cambridge: Cambridge University Press 2013).

Reyntjens, Filip, The Great African War: Congo and Regional Geopolitics, 1996-2006 (Cambridge: Cambridge University Press 2009).

Richards, Joanne, 'Troop Retention in Civil Wars: Desertion, Denunciation, and Military Organization in the Democratic Republic of Congo', Journal of Global Security Studies 3/1 (2018) 38-55.

Roberts, George, 'The Uganda-Tanzania War, the Fall of Idi Amin, and the Failure of African Diplomacy, 1978-1979', Journal of Eastern African Studies 8/4 (2014) 692-709.

Roessler, Philip, and Harry Verhoeven, Why Comrades Go To War: Liberation Politics and the Outbreak of Africa's Deadliest Conflict (New York: Oxford University Press 2016).

Salehyan, Idean, 'Transnational Rebels: Neighboring States as Sanctuary for Rebel Groups', World Politics 59/2 (2007) 217-42.

Sawyer, Katherine, Kathleen Gallagher Cunningham, and William Reed, 'The Role of External Support in Civil War Termination', Journal of Conflict Resolution 61/6 (2017) 1174-202.

Schubiger, Livia Isabella, 'One for All? State Violence and Insurgent Cohesion', paper presented at the Annual Convention of the International Studies Association, New Orleans, LA, February 2015.

Slater, Dan, and Daniel Ziblatt, 'The Enduring Indispensability of the Controlled Comparison', Comparative Political Studies 46/10 (2013) 1301-27.

Soderlund, Walter C., E. Donald Briggs, Tom Pierre Najem, and Blake C. Roberts, Africa's Deadliest Conflict: Media Coverage of the Humanitarian Disaster in the Congo and the United Nations Response, 1997-2008 (Waterloo: Wilfrid Laurier University Press 2012).

Staniland, Paul, Networks of Rebellion: Explaining Insurgent Cohesion and Collapse (Ithaca, NY: Cornell University Press 2014).

Stearns, Jason, Banyamulenge: Insurgency and Exclusion in the Mountains of South Kivu (London: Rift Valley Institute 2013).

Stearns, Jason, From CNDP to M23: The Evolution of an Armed Movement in Eastern Congo (London: Rift Valley Institute 2012).

Stearns, Jason K., Dancing in the Glory of Monsters: The Collapse of the Congo and the Great War of Africa (New York: Public Affairs 2011). 
Tamm, Henning, 'Status Competition in Africa: Explaining the Rwandan-Ugandan Clashes in the Democratic Republic of Congo', African Affairs 118/472 (2019) 509-30.

Tamm, Henning, 'Rebel Leaders, Internal Rivals, and External Resources: How State Sponsors Affect Insurgent Cohesion', International Studies Quarterly 60/4 (2016) 599-610.

Tamm, Henning, 'The Origins of Transnational Alliances: Rulers, Rebels, and Political Survival in the Congo Wars', International Security 41/1 (2016) 147-81.

Tamm, Henning, UPC in Ituri: The External Militarization of Local Politics in North-Eastern Congo (London: Rift Valley Institute 2013).

Tareke, Gebru, The Ethiopian Revolution: War in the Horn of Africa (New Haven, CT: Yale University Press 2009).

Tareke, Gebru, 'The Ethiopia-Somalia War of 1977 Revisited', International Journal of African Historical Studies 33/3 (2000) 635-67.

Tarrow, Sidney G., 'The Strategy of Paired Comparison: Toward a Theory of Practice', Comparative Political Studies 43/2 (2010) 230-59.

Titeca, Kristof, 'Access to Resources and Predictability in Armed Rebellion: The FAPC's Short-lived "Monaco" in Eastern Congo', Africa Spectrum 62/2 (2011) 43-70.

Tripp, Aili Mari, Museveni's Uganda: Paradoxes of Power in a Hybrid Regime (Boulder, CO: Lynne Rienner 2010).

United Nations Security Council (UNSC), 'Twelfth Report of the Secretary-General on the United Nations Organization Mission in the Democratic Republic of the Congo', S/2002/1180, New York, 18 October 2002.

Vlassenroot, Koen, Sandrine Perrot, and Jeroen Cuvelier, 'Doing Business Out of War: An Analysis of the UPDF's Presence in the Democratic Republic of Congo', Journal of Eastern African Studies 6/1 (2012) 2-21.

Vlassenroot, Koen, and Timothy Raeymaekers, 'The Politics of Rebellion and Intervention in Ituri: The Emergence of a New Political Complex?', African Affairs 103/412 (2004) 385412.

Wamba dia Wamba, Ernest, 'Crisis in the Congolese Rally for Democracy (RCD): Struggle of antagonist political lines', June 1999.

Weinstein, Jeremy M., Inside Rebellion: The Politics of Insurgent Violence (Cambridge: Cambridge University Press 2007).

Woldemariam, Michael, Insurgent Fragmentation in the Horn of Africa: Rebellion and Its Discontents (Cambridge: Cambridge University Press 2018). 
Zverev, Anton, 'Ex-Rebel Leaders Detail Role Played by Putin Aide in East Ukraine', Reuters, 11 May 2017, https://www.reuters.com/article/us-ukraine-crisis-russia-surkov-insightidUSKBN1870TJ. 